\title{
Increased expression of PIN1 gene in papillary thyroid carcinoma
}

\author{
Andrzej Lewiński ${ }^{1,2^{*}}$, Ewa Brzeziańska ${ }^{3}$, Karolina Czarnecka $^{3}$, Joanna Latek², Włodzimierz Koptas ${ }^{4}$, \\ Anna Cyniak-Magierska ${ }^{1,2}$
}

\begin{abstract}
Background: Peptidyl-prolyl cis/trans isomerase (Pin1), encoded by PIN1 gene with locus in chromosome 19p13, is an enzyme that catalytically induces conformational changes in proteins after phosphorylation on serine or threonine residues preceding proline (pSer/Thr-Pro motifs); in this way, it has an influence on protein interactions and intracellular localizations of proteins. The aim of the study were: 1) an assessment of PIN1 gene expression level in benign and malignant thyroid lesions; 2) the evaluation of possible correlations between gene expression and histopathological variants of papillary thyroid carcinoma (PTC) or tumour size, classified according to TNM classification of primary tumours (in case of PTC only); 3) the estimation of possible relationships between expression of the gene in question and patients' sex or age.

Methods: Seventy (70) tissue samples were analyzed: 32 cases of PTC, 7 cases of medullary thyroid carcinoma (MTC), 7 cases of follicular adenoma (FA), and 24 cases of nodular goitre (NG). In real-time polymerase chain reaction (real-time PCR), two-step RT-PCR (reverse transcriptase-polymerase chain reaction) in an ABI PRISM 7500 Sequence Detection System was employed. The PIN1 gene expression level was assessed, calculating the mean relative quantification rate $(\mathrm{RQ}$ rate) increase for each sample.

Results: The level of PIN1 gene expression (compared to that in macroscopically unchanged thyroid tissue) was higher in PTC group than those in FA, MTC and/or NG groups, but the statistical significance was noted for difference between PTC and NG groups only. On the other hand, the differences of RQ rate value between different PTC variants were statistically insignificant. No correlations were found between RQ values and tumour size, as well as between RQ values and patients' sex or age in PTC group.

Conclusions: The PIN1 gene expression may have - in future - an important meaning in the diagnostics of PTC and in understanding its pathogenesis. However, our results - mostly due to the small number of cases - do not yet allow considering PIN1 gene as a prognostic molecular PTC marker.
\end{abstract}

\section{Background}

The PIN1 gene encodes an essential peptidyl-prolyl cis/ trans isomerase (PPIase; EC 5.2.1.8) which has a profound impact on key proteins involved in the regulation of cell cycle [1]. The human PIN1 gene is mapped to chromosome 19p13 [2]. Catalyzing conformational changes in substrates after phosphorylation, Pin1 recognizes phospho-serine or phospho-threonine bonds followed by proline (pSer/Thr-Pro motifs) and plays a vital role in protein folding or refolding [3]. Through

\footnotetext{
* Correspondence: alewin@csk.umed.lodz.pl

'Department of Endocrinology and Metabolic Diseases, Medical University of Lodz, Poland

Full list of author information is available at the end of the article
}

isomerization Pin1 can modulate the conformation of protein substrates, changing their enzymatic activity which leads to alteration in different cell function [1].

Pin1 enzyme activity is important for oncogenic and cell-signalling pathways via conformational changes following phosphorylation of many molecules (e.g. Bcl-2, p53, c-Jun, beta-catenin, cyclin D1 and RAF kinase) [4-7]. The Pin1-regulated alteration in protein interactions and stability have been shown to be associated with cell transformation and progression of certain types of human tumours (e.g., prostate, colon, lung, ovary and breast cancers, and lymphoma) [8-10]. It has also been reported that inhibition of Pin 1 function in human tumour cells, using Pin1 antisense RNA, induces mitotic

\section{Biomed Central}


arrest and apoptosis [11]. Further studies indicate that Pin1 plays a critical role in cell restriction points - particularly in G1/S phase; Pin1 modulates some important regulators of that cell cycle point, e.g. cyclin D1 and its upstream transcriptional factors. The increased Pin1 expression correlates significantly with overexpression of cyclin D1 mRNA and protein. Interestingly, Pin1 binds phosphorylated c-Jun, influencing the increase of its transcriptional activity towards cyclin D1 - by activating c-Jun/AP-1 and beta-catenin/T-cell factor (TCF) and, in this way it cooperates with Ras signalling pathway [4].

Pin1 is involved not only in the pathogenesis of human cancer, but - presumably - also in the pathogenesis of asthma and Alzheimer's disease [12].

Recently, in some reports - including the study on thyroid tumours - strong correlation between Pin1 and cyclin D1 immunoexpression and/or cyclin D1 mRNA and PIN1 expression via interaction with Wnt signalling pathway has been observed [13]. Moreover, it has been suggested that Pin1 may promote cyclin D1 overexpression directly or through accumulation of beta-catenin in thyroid cancer cells [13].

There are rather scarce reports which are focused on evaluation of PIN1 mRNA expression in thyroid tumours. Therefore, in order to recognize the Pin1 role in the pathogenesis of thyroid gland, we have compared the levels of PIN1 gene expression in benign and malignant thyroid lesions. We have assessed PIN1 gene expression in real-time polymerase chain reaction (realtime PCR), two-step RT-PCR (reverse transcriptasepolymerase chain reaction) and we have evaluated the possible correlations between the gene expression and the histopathological variant of examined PTCs (classic, tall-cell, follicular), tumour size grouped according to TNM classification of primary tumours (pT1, pT2, pT3, pT4). We have also decided to estimate the possible relationships between expression of the gene in question and patients' sex or age.

\section{Materials and methods}

The Ethical Committee of the Medical University of Lodz approved the studies reported in the present article.

\section{Thyroid tissue samples}

Tumour tissue samples (100-150 mg) were obtained from 70 patients who had undergone surgery treatment at the Centre of Oncology, the Maria Skłodowska-Curie Institute in Gliwice, at the Holy Family Municipal Hospital in Lodz and at the Department of General and Colorectal Surgery, Medical University of Lodz, Poland during the years 2002-2007. Total tumour tissue samples, immediately after resection, were collected into lysis buffer (Buffer RLT, Qiagen Sciences, USA).
Among the studied samples 32 cases of primary papillary thyroid carcinoma - PTC ( 26 females, 6 males; mean age $41.8 \pm 15.7$; mean \pm SD) were used. Histopathological variants of PTC were as follows: PTC classic variant (20 cases: 17 females, 3 males; mean age $36.5 \pm 14.4)$, PTC follicular variant ( 9 cases: 6 females, 3 males; mean age $49.9 \pm 16.0$ ), PTC tall-cell variant ( 3 cases: 3 females; mean age $53.3 \pm$ 5.1) (Table 1). Seven (7) cases of medullary thyroid carcinoma - MTC ( 6 females, 1 male; mean age $56.0 \pm 17.6$ ) and 7 cases of follicular adenoma - FA ( 6 females, 1 male; mean age $49.4 \pm 14.8$ ) were also included in the study. The control group consisted of 24 cases of nodular goitre - NG (22 females, 2 males; mean age $48.9 \pm 14.7$ ) (Table 2).

The whole study cohort comprised 70 persons: 60 females and 10 males, the mean age was $46.4 \pm 15.8$ years (age ranged from 16 to 75 years). Histopathological diagnoses for malignant thyroid lesions, according to WHO Classification of Tumours [14], have been obtained from pathomorphological reports and are presented in Table 1, together with TNM classification and AJCC stage groupings [15].

In the study design, macroscopically unchanged thyroid tissue served for the reference standard (calibrator).

\section{Isolation of total RNA and reverse transcription (RT)}

Total RNA was extracted from fresh tisssues, using RNeasy Protect Midi Kit, (Qiagen, Hilden, Germany), according to the manufacturer's recommendations. RNA concentration was spectrophotometrically assessed by measuring absorbance at 260 and $280 \mathrm{~nm}$ (Ultraspec 2000 UV/Visible Spectrophotometer, Pharmacia Biotech, Sweden).

Afterwards the reverse transcription (RT) was performed in a Personal Thermocycler (Eppendorf, Germany), using $1 \mu \mathrm{g}$ of total RNA in the presence of 50 $\mu \mathrm{M}$ of oligo $\mathrm{d}(\mathrm{T}) 16$ and Reverse Transcriptase MultiScribe $^{\mathrm{mix}}(50 \mathrm{U} / \mu \mathrm{l})$ in a total volume of $30 \mu \mathrm{l}$, including also: 10× TaqMan RT Buffer (containing $100 \mathrm{mM}$ TrisHCL pH 8.3, $500 \mathrm{mM} \mathrm{KCL}), \mathrm{MgCl}_{2}$ solution $(25 \mathrm{mM})$, dNTPs mixture $(10 \mathrm{mM})$, RNAse Inhibitor $(20 \mathrm{U} / \mu \mathrm{l})$, and nuclease-free water (TaqMan Reverse Transcriptase Reagents, Applied Biosystems, Foster City, CA, USA). The reactions were conducted for 10 minutes at $25^{\circ} \mathrm{C}$, followed by 30 minutes at $48^{\circ} \mathrm{C}$, afterwards the samples were heated for $5 \mathrm{~min}$ to $95^{\circ} \mathrm{C}$, and next placed at $4^{\circ} \mathrm{C}$. The cDNA concentration and purity were spectrophotometrically assessed by measuring absorbance at 260 and $280 \mathrm{~nm}$ (Ultraspec 2000 UV/Visible Spectrophotometer, Pharmacia Biotech, Sweden).

\section{Quantitative analysis of the relative amount of PIN1 mRNA by real-time PCR}

An established Relative Quantification Polymerase Chain Reaction (RQ-PCR) assay for PIN1 mRNA expression 
Table 1 Sex, age, histopathological diagnosis of malignant thyroid tumours in the studied patients

\begin{tabular}{|c|c|c|c|c|c|}
\hline $\begin{array}{c}\text { Case } \\
\text { number }\end{array}$ & Sex & Age & $\begin{array}{l}\text { Histopathological } \\
\text { diagnosis }\end{array}$ & $\begin{array}{l}\text { TNM staging } \\
\text { system }\end{array}$ & $\begin{array}{l}\text { American Joint Committee on Cancer (AJCC) grouping } \\
\text { system }\end{array}$ \\
\hline 1 & $\mathrm{~F}$ & 23 & PTC, classic variant & pT1bNxM0 & 1 \\
\hline 2 & $\mathrm{~F}$ & 38 & PTC, classic variant & pT1NOMO & 1 \\
\hline 3 & $\mathrm{~F}$ & 52 & PTC, classic variant & pT2NOMO & $\|$ \\
\hline 4 & $\mathrm{~F}$ & 71 & PTC, classic variant & pT2NOMx & $\|$ \\
\hline 5 & $\mathrm{~F}$ & 47 & PTC, classic variant & pT1aNOMO & 1 \\
\hline 6 & $\mathrm{~F}$ & 24 & PTC, classic variant & pT1N0Mx & 1 \\
\hline 7 & $\mathrm{~F}$ & 33 & PTC, classic variant & pT2aNxMx & $\|$ \\
\hline 8 & $\mathrm{~F}$ & 28 & PTC, classic variant & pT1bNxMx & 1 \\
\hline 9 & $\mathrm{~F}$ & 40 & PTC, classic variant & pT4NOMx & IVA \\
\hline 10 & $\mathrm{~F}$ & 17 & PTC, classic variant & pT2bN1aM0 & III \\
\hline 11 & M & 47 & PTC, classic variant & pT2aN1aM0 & III \\
\hline 12 & M & 31 & PTC, classic variant & pT2aNOMO & $\|$ \\
\hline 13 & $\mathrm{~F}$ & 16 & PTC, classic variant & pT2aNOMO & $\|$ \\
\hline 14 & $\mathrm{~F}$ & 61 & PTC, classic variant & pT2aNOMO & $\|$ \\
\hline 15 & $\mathrm{~F}$ & 48 & PTC, classic variant & pT4N1aM0 & IVA \\
\hline 16 & M & 30 & PTC, classic variant & pT4N1bM0 & IV \\
\hline 17 & $\mathrm{~F}$ & 31 & PTC, classic variant & pT1NxMx & I \\
\hline 18 & $\mathrm{~F}$ & 40 & PTC, classic variant & pT1aNxMx & 1 \\
\hline 19 & $\mathrm{~F}$ & 28 & PTC, classic variant & pT1aNxMx & I \\
\hline 20 & $\mathrm{~F}$ & 25 & PTC, classic variant & pT1aN1aMx & 1 \\
\hline 21 & $\mathrm{~F}$ & 49 & PTC, tall-cell variant & pT2bNOM0 & $\|$ \\
\hline 22 & $F$ & 52 & PTC, tall-cell variant & pT4NOMO & IVA \\
\hline 23 & $\mathrm{~F}$ & 59 & PTC, tall-cell variant & pT4bN1Mx & IV \\
\hline 24 & $\mathrm{~F}$ & 36 & PTC, follicular variant & pT2aNxMx & $\|$ \\
\hline 25 & M & 28 & PTC, follicular variant & pT2N1aMx & $\|$ \\
\hline 26 & M & 52 & PTC, follicular variant & pT3NxMx & III \\
\hline 27 & $\mathrm{~F}$ & 62 & PTC, follicular variant & pT1aNxMx & 1 \\
\hline 28 & $\mathrm{~F}$ & 26 & PTC, follicular variant & pT4N1aM0 & IVA \\
\hline 29 & $\mathrm{~F}$ & 56 & PTC, follicular variant & pT3aNOMO & III \\
\hline 30 & $\mathrm{~F}$ & 68 & PTC, follicular variant & pT2bN1aM0 & $\|$ \\
\hline 31 & M & 66 & PTC, follicular variant & pT4aNOMO & IVA \\
\hline 32 & $\mathrm{~F}$ & 55 & PTC, follicular variant & pT2aNOMO & $\|$ \\
\hline 33 & M & 74 & MTC & pT4NOM0 & IVA \\
\hline 34 & $\mathrm{~F}$ & 32 & MTC & pT1NxMx & 1 \\
\hline 35 & $F$ & 32 & MTC & pT1NxMx & 1 \\
\hline 36 & $\mathrm{~F}$ & 59 & MTC & pT3N1bM0 & III \\
\hline 37 & $\mathrm{~F}$ & 56 & MTC & pT3NOMO & III \\
\hline 38 & $\mathrm{~F}$ & 71 & MTC & pT4N1aM0 & IVA \\
\hline 39 & $\mathrm{~F}$ & 68 & MTC & pT3aNOMO & III \\
\hline
\end{tabular}

was conducted in ABI PRISM 7500 Sequence Detection System (Applied Biosystems), according to the manufacturer's protocol. The PCR reactions for PIN1 gene were run with $50 \mathrm{ng}$ of cDNA in a total volume of $50 \mu \mathrm{l}$, using TaqMan ${ }^{\circledR}$ Universal PCR Master Mix (Applied Biosystems, Foster City, CA, USA) and the predesigned and labelled primer/probe set (Assays-on-Demand ${ }^{\mathrm{ma}}$ Gene Expression assay mix, Hs01598309_ml, Applied Biosystems). After initial incubation at $50^{\circ} \mathrm{C}$ for $2 \mathrm{~min}$ to allow uracil-N-glycosylase (UNG) digestion, and at $95^{\circ} \mathrm{C}$ for 10 min to activate the AmpliTaq Gold ${ }^{\mathbb{B}}$ DNA polymerase, both of them were provided by the 
Table 2 Sex, age, histopathological diagnosis of benign thyroid lesions in the studied patients

\begin{tabular}{|c|c|c|c|}
\hline Case number & Sex & Age & Histopathological diagnosis \\
\hline 1 & $\mathrm{~F}$ & 49 & FA \\
\hline 2 & $\mathrm{~F}$ & 52 & $\mathrm{FA}$ \\
\hline 3 & M & 75 & FA \\
\hline 4 & $\mathrm{~F}$ & 29 & FA \\
\hline 5 & $\mathrm{~F}$ & 41 & FA \\
\hline 6 & $\mathrm{~F}$ & 41 & FA \\
\hline 7 & $\mathrm{~F}$ & 59 & FA \\
\hline 8 & $\mathrm{~F}$ & 40 & NG \\
\hline 9 & $\mathrm{~F}$ & 42 & NG \\
\hline 10 & $\mathrm{~F}$ & 30 & NG \\
\hline 11 & $\mathrm{~F}$ & 48 & NG \\
\hline 12 & $\mathrm{~F}$ & 42 & NG \\
\hline 13 & $\mathrm{~F}$ & 64 & NG \\
\hline 14 & $\mathrm{~F}$ & 69 & NG \\
\hline 15 & $\mathrm{~F}$ & 72 & NG \\
\hline 16 & $\mathrm{~F}$ & 50 & NG \\
\hline 17 & $\mathrm{~F}$ & 51 & NG \\
\hline 18 & $F$ & 63 & NG \\
\hline 19 & $\mathrm{~F}$ & 49 & NG \\
\hline 20 & $\mathrm{~F}$ & 49 & NG \\
\hline 21 & $\mathrm{~F}$ & 38 & NG \\
\hline 22 & $M$ & 52 & $N G$ \\
\hline 23 & $F$ & 31 & NG \\
\hline 24 & $F$ & 29 & $N G$ \\
\hline 25 & $M$ & 75 & NG \\
\hline 26 & $\mathrm{~F}$ & 28 & $N G$ \\
\hline 27 & $F$ & 30 & NG \\
\hline 28 & $\mathrm{~F}$ & 72 & NG \\
\hline 29 & $\mathrm{~F}$ & 50 & NG \\
\hline 30 & $F$ & 40 & NG \\
\hline 31 & $\mathrm{~F}$ & 59 & NG \\
\hline
\end{tabular}

Universal PCR Master Mix, the samples were amplified through 40 biphasic cycles of $95^{\circ} \mathrm{C}$ for $15 \mathrm{sec}$ and $60^{\circ} \mathrm{C}$ for 1 min (Table 3).

Macroscopically unchanged thyroid tissue was used as a calibrator (standard sample). Amplification reactions were done in triplicate for each sample (cDNA from the same PCR reaction but in separate wells). Controls with no template cDNA were used with each assay (negative control).

The expression levels of $\beta$-actin gene (ACTB) were measured, as endogenous control (reference gene), using the appropriate Assays-on-Demand ${ }^{\mathrm{m}}$ Gene Expression product (Hs99999903_ml, Applied Biosystems Foster City, CA, USA).
Table 3 Real-time PCR conditions for PIN1 gene amplification

\begin{tabular}{|c|c|c|c|}
\hline \multicolumn{4}{|c|}{ Times and temperatures } \\
\hline \multicolumn{2}{|l|}{ Initial setup } & \multicolumn{2}{|c|}{ Each of 40 cycles } \\
\hline & & Denaturation & $\begin{array}{l}\text { Annealing/ } \\
\text { Elongation }\end{array}$ \\
\hline HOLD & HOLD & \multicolumn{2}{|c|}{ CYCLE } \\
\hline $\begin{array}{l}\text { UNG activation } 2 \mathrm{~min} \text {, } \\
50^{\circ} \mathrm{C}\end{array}$ & $\begin{array}{l}10 \min \\
95^{\circ} \mathrm{C}\end{array}$ & $15 \mathrm{~s}, 95^{\circ} \mathrm{C}$ & $1 \mathrm{~min}, 60^{\circ} \mathrm{C}$ \\
\hline
\end{tabular}

Both gene expressions were measured for each thyroid lesion sample in the same PCR reaction but in separate wells.

Assays-on-Demand ${ }^{\text {tw }}$ Gene Expression product consists of $20 \times$ mix of unlabelled PCR primers $(18 \mu \mathrm{M}$ for each) and TaqMan ${ }^{\circledR}$ MGB probes $(5 \mu \mathrm{M})$ with FAM $^{\mathrm{Tm}}(6$-carboxy-fluorescein) at the 5 ' end as the reporter dye, and a non-fluorescent quencher (TAMRA, 6-carboxy-tetramethylrhodamine) at the $3^{\prime}$ end. The two-minute, $50^{\circ} \mathrm{C}$ step was required for optimal AmpErase ${ }^{\circledR}$ UNG activity when TaqMan $^{\circledR}$ Universal PCR Master Mix (P/N 4304437) was used.

The fluorescence signal was measured in real-time PCR in the extension phase of the PCR reaction, and the measurement, proportional to the quantity of sample cDNA in the reaction, was plotted as an amplification curve against cycle number. A threshold value of fluorescence in the exponential part of the amplification curve was selected, and - for each sample - the number of cycles was measured, which was needed by the signal to reach the threshold (threshold cycle, $\mathrm{C}_{\mathrm{T}}$ ). The larger were the quantities of the starting material, the lower were $\mathrm{C}_{\mathrm{T}}$ values.

\section{Data analysis}

Data analysis of relative gene expression was performed with the Taq-Man SDS analysis software on an ABI PRISM 7500 Sequence Detection System (Applied Biosystems), and the results were exported to Excel sheets for further processing.

Fluorescence emission data were determined as $C_{T}$ values for each reaction and, for each sample, triplicate $C_{T}$ values were averaged. The average $C_{T}$ value for $\beta$ actin was subtracted from the average PIN1 $\mathrm{C}_{\mathrm{T}}$ value to yield the $\Delta C_{T}$ value $\left(\Delta C_{T}=C_{T}\right.$ target $-C_{T}$ reference $)$. Normalization to the reference gene $(\beta$-actin) has been necessary to account for the variabilities in sample quantity and quality, and for the variabilities in PCR efficiency among samples. The assay, described in this report, involves the determination of a $\Delta \Delta \mathrm{C}_{\mathrm{T}}$ value. This is calculated by: $\Delta \Delta C_{T}=\Delta C_{T}$ test sample $-\Delta C_{T}$ calibrator sample. The higher is the $\Delta \Delta \mathrm{C}_{\mathrm{T}}$ value, the lower is the expression of PIN1 in the specimen. Fold- 
differences, representing relative expression results, are calculated using the following equation: relative fold increase $=2^{-\Delta \Delta C} \mathrm{~T}$. In order to evaluate the analytical sensitivity, specificity, and accuracy of the assay, serial dilutions were performed.

\section{Statistical analysis}

The data were statistically analyzed, using NewmanKeuls' multiple comparison test followed by KruskalWallis' test, in order to compare the level of expression values (RQ) among the four studied independent groups (PTC, MTC, FA, NG). Basic measures of location (i.e. mean, median), measures of dispersion (SD, SEM), and minimum and maximum values were calculated to provide detailed descriptions of gene expressions in selected groups. Additionally, box-and-whiskers plots were introduced to display the difference in gene expressions levels in different samples.

The Kruskal-Wallis' test was used to compare the level of expression values (RQ) among three variants of PTC (PTC v. classic, PTC v. tall-cell, PTC v. follicular). The Spearman's rank correlation coefficient and U Mann-Whitney's test were performed in order to correlate the level of expression of PIN1 gene (RQ values) with examined parameters (age, sex, tumour size, classified according to TNM definition of primary tumours pT1, pT2, pT3, pT4).

The accepted level of statistical significance was at $\mathrm{p}<$ 0.05 . The results are presented as means \pm SEM and means $\pm \mathrm{SD}$ values.

Statistica for Windows 7.0 program was applied for calculations.

\section{Results}

The specimens were amplified in the ABI PRISM 7500 Sequence Detection System in reaction, containing primers and probes for PIN1 gene and a control gene, $\beta$ actin. The Sequence Detection System software, provided with the instrument, analyses the fluorescence data, generated during the reaction, and calculates the cycle number at which fluorescence crosses the threshold value $\left(C_{T}\right)$. Triplicate amplifications of the sample produced nearly identical, overlapping curves, from which $C_{T}$ values were calculated.

In our experiment low $\mathrm{C}_{\mathrm{T}}$ values for PIN1 gene in all malignant thyroid tissues (PTC - 32 and MTC - 7 specimens) were observed.

The assay, described in this paper, was based on the determination of a $\Delta \Delta C_{\mathrm{T}}$ value $\left(\Delta \Delta \mathrm{C}_{\mathrm{T}}\right.$ method) for each sample (the greater was the $\Delta \Delta \mathrm{C}_{\mathrm{T}}$ value, the lower was the expression of PIN1 gene) and on calculating the difference in PIN1 expression level between tumour sample and calibrator (RQ value). The results for calculated RQ in the studied groups (PTC, MTC, FA, NG) are
Table 4 The expression level (RQ) of PIN1 gene, calculated by the $\Delta \Delta C_{T}$ method in the studied groups

\begin{tabular}{cccc}
\hline Group & No. of cases & Mean RQ & Range of RQ values \\
\hline PTC & 32 & 6.72 & $0.363-52.279$ \\
\hline MTC & 7 & 5.55 & $0.917-19.408$ \\
\hline FA & 7 & 2.79 & $0.511-8.207$ \\
\hline NG & 24 & 2.15 & $0.322-13.153$ \\
\hline
\end{tabular}

presented in Table 4. The RQ value for PTC, classic variant, ranged from 0.441 to 52.279 (the mean RQ was 8.43); for PTC, follicular variant, ranged from 0.804 to 9.124 (the mean RQ was 3.03) and for PTC, tall-cell variant, ranged from 0.363 to 12.616 (the mean RQ was 6.42).

Kruskal-Wallis' test, applied for RQ comparison between the four studied groups (PTC, MTC, FA, NG), showed statistically significant differences $(p=0.0233)$ among them (Figure 1). The results of Newman-Keuls' multiple comparison test revealed statistically significant differences in RQ values only between the PTC group (higher RQ values) and the control group - NG ( $\mathrm{p}=$ $0.031977)$. In cases of other groups, the differences in RQ values were not significant $(\mathrm{p}>0.05)$ (Table 5). Similarly, the results of Kruskal-Wallis' test did not show any significant differences among the particular variants of PTC (PTC v. classic, PTC v. tall-cell, PTC v. follicular) $(\mathrm{p}=0.9501)$ (Figure 2). Additionally, in the whole studied group of PTCs, no correlations were

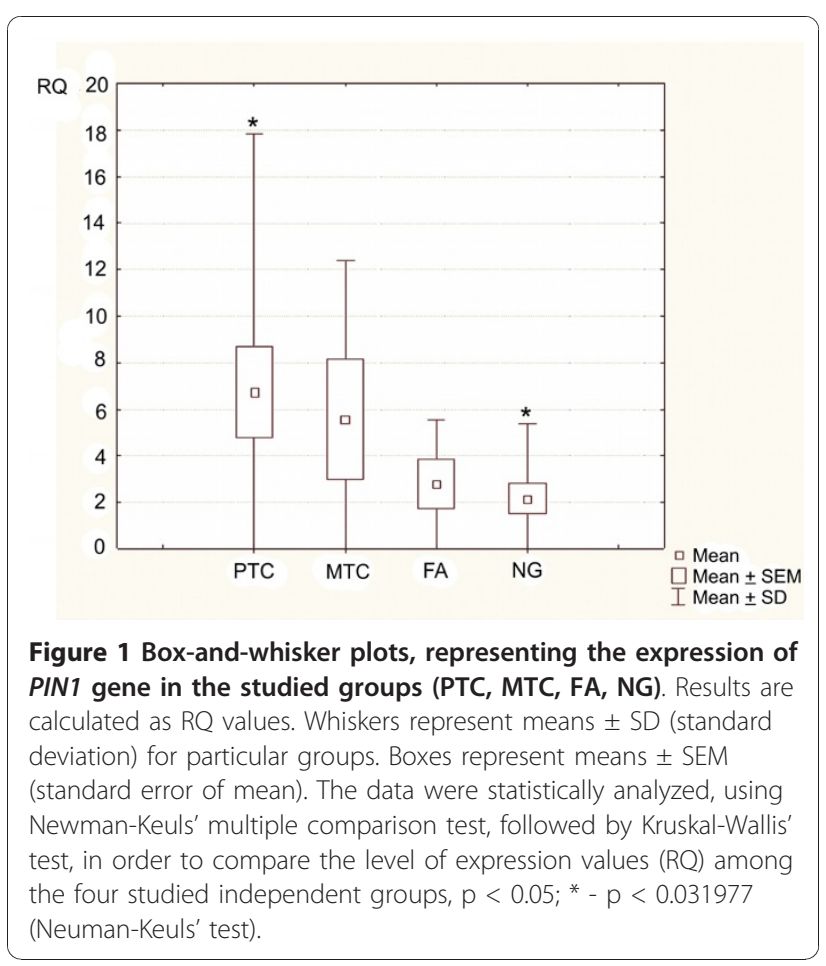


Table 5 Statistical analysis of results - comparison of RQ value among the four studied groups (PTC, MTC, FA, NG). Newman-Keuls' test, $p$ - level of significance

\begin{tabular}{ccccc}
\hline & PTC & MTC & FA & NG \\
\hline PTC & & 1.000000 & 1.000000 & $\mathbf{0 . 0 3 1 9 7 7}$ \\
\hline MTC & 1.000000 & & 1.000000 & 0.154248 \\
\hline FA & 1.000000 & 1.000000 & & 1.000000 \\
\hline NG & $\mathbf{0 . 0 3 1 9 7 7}$ & 0.154248 & 1.000000 & \\
\hline
\end{tabular}

found between PIN1 expression level and patients' sex, age or tumour size $(\mathrm{p}>0.05)$. The results of MannWhitney's U test confirmed no significant differences in RQ values between the PTC group and MTC group ( $\mathrm{p}$ $=0.6873$ ) (Figure 3).

\section{Discussion}

The molecular pathogenesis of thyroid cancer is very complex and still unclear. Recent molecular studies on thyroid carcinogenesis have proved that many specific genetic alterations in protooncogenes are associated with development of thyroid cancer $[16,17]$. The mutational activation of MAPK/ERK signalling pathway is crucial to understand the carcinogenesis in the thyroid. The mutations of genes coding effectors of MAPK/ERK pathway (RET, RAS, NTRK1, BRAF) which rarely overlap, may be identified in more than $70 \%$ of PTC cases [18-20]. Additionally, the chromosomal rearrangements (RET/PTC or Trk) appear to be of crucial importance in activation of MAPK/ERK pathway [21,22].

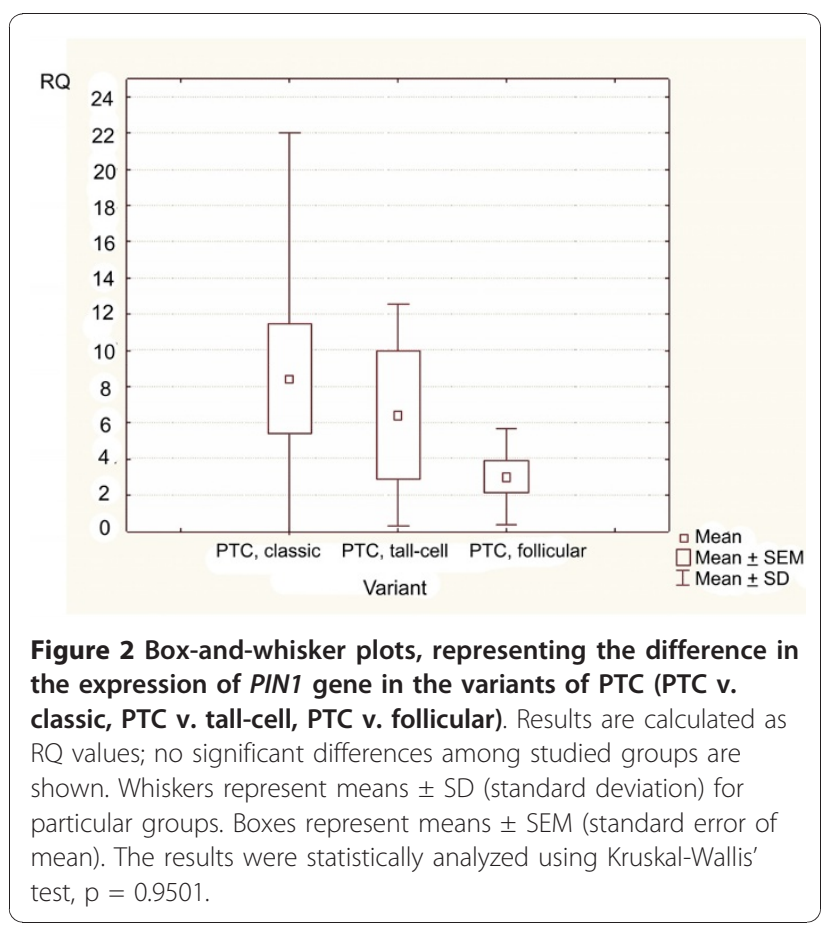

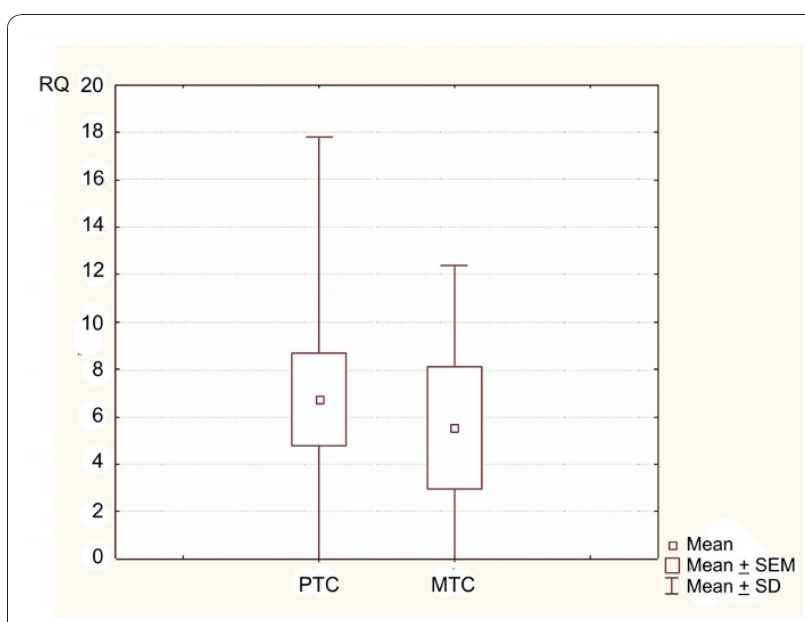

Figure 3 Box-and-whisker plots, representing the difference in the expression of PIN1 gene between the PTC group and the MTC group. Results are calculated as RQ values; no significant differences between studied groups are demonstrated. Whiskers represent means \pm SD (standard deviation) for particular groups. Boxes represent means \pm SEM (standard error of mean). The results were statistically analyzed using Mann-Whitney's $U$ test, $p=0.6873$.

Despite the fact that constitutive activation of the above mentioned pathway is a very important for the development of thyroid cancer, many other molecular regulatory mechanisms, involved in thyroid cancer transformation, are recognized.

In our study, we have examined whether the PIN1 gene participates in thyroid carcinogenesis.

The phosphorylation of proteins on serine or threonine residues preceding proline (pSer/Thr-Pro motifs), catalized by the peptidyl-prolyl cis/trans isomerase Pin1, has been confirmed as a major cell transformation mechanism activating different oncogenic pathways in many types of human tumours (including thyroid cancer) $[9,13,23,24]$. In immunohistochemical studies of thyroid tumours, as well as of other types of cancers (e. g., oral squamous carcinoma), high Pin1 expression promotes cyclin D1 overexpression, directly or through accumulation of beta-catenin $[13,25]$. It has been reported that PIN1 expression is regulated by the transcription factor E2F and Neu/Ras signalling. The enhanced expression and stability of cyclin D1 by transcriptional activation and/or posttranslational stabilization by PIN1 gene or Pin 1 protein may lead to cell proliferation and transformation. Therefore, PIN1 might be a crucial factor in modulating upregulation of cyclin D1 level by Neu/Ras oncogenic signalling $[7,26]$.

Bearing in mind all these facts, in our present study, we have assessed PIN1 gene expression level in benign and malignant thyroid lesions. In our earlier study, we demonstrated that cyclin $D 1$ gene expression levels were higher in malignant thyroid tumours (PTC, MTC), 
when compared to those in NG or FA groups [27]. Our present results have revealed statistically significant differences in expression of PIN1 mRNA between PTC group and benign thyroid lesions (FA, NG) (higher RQ value in PTC). It should be stressed that our data are in accordance with observations of other authors [13]. Nakashima et al. [13] have observed overexpression of cyclin D1 mRNA in PTC (thyroid tumours from a radiocontaminated area), taking course with high expression of PIN1 gene. In the quoted paper, correlation between high Pin1 protein level and cyclin D1 immunoexpression level in PTC has also been confirmed [13]. It is important that Pin1 can promote cyclin D1 overexpression directly or through beta-catenin stabilization [6,13]. Our present results, which have focused on PIN1 mRNA expression, as well as our earlier data, concerning cyclin D1 mRNA overexpression in thyroid malignancy, may suggest that one of the major regulatory mechanisms in cell transformation in thyroid carcinogenesis is PIN1 gene activity [27]. It is tempting to speculate that PIN1 gene positively regulates cyclin D1 gene function not only through posttranslational stabilization but also by an effect on transcriptional level.

In our present study, we have applied real-time relative quantification PCR assay for PIN1 mRNA expression and, employing this extremely sensitive and precise method, we have confirmed overexpression of PIN1 gene in PTC. These results may suggest a diagnostic utility of PIN1 mRNA expression - as a malignant lesion marker for thyroid PTC. However, the results should be confirmed in larger number of PTC cases. The utility of PIN1 gene may be - in future - very crucial for diagnostics and treatment of thyroid cancer (especially of PTC), based on the facts that overexpression of Pin1 has been found to be an excellent prognostic marker in some other human cancers (e.g., prostate, breast, colorectal cancers) $[8,10,23]$. In these immunohistochemical studies, strong relationship between Pin1 protein level and clinical outcome has been observed $[8,10,23]$. Unfortunately, it is difficult to discuss the relationship between PIN1 mRNA and prognosis in PTC, because - according to our knowledge - there were no reported studies, focusing on the evaluation of PIN1 gene expression in association with pathological features and clinical outcome of PTC, so far. Our present data have not documented any significant differences in the expression level of PIN1 mRNA among the particular variants of PTC (classic vs. tall-cell, vs. follicular variants). Moreover, no correlations were found between PIN1 expression level and patients' sex, age or tumour size in PTC group.

In summary, PIN1 gene expression may have - in future - certain significance in PTC diagnostics and in understanding its pathogenesis. However, our results due to the small number of cases - do not yet allow considering PIN1 gene as a prognostic molecular PTC marker.

\section{Acknowledgements}

This study was supported by the funds from the Medical University of Lodz, Poland (project no. 502-11-570).

\section{Author details}

${ }^{1}$ Department of Endocrinology and Metabolic Diseases, Medical University of Lodz, Poland. '2Department of Endocrinology and Metabolic Diseases, Polish Mother's Memorial Hospital - Research Institute, Lodz, Poland. ${ }^{3}$ Department of Molecular Basis of Medicine, Medical University of Lodz, Poland.

${ }^{4}$ Department of General and Colorectal Surgery, Medical University of Lodz, Poland.

\section{Authors' contributions}

$\mathrm{AL}$ designed and coordinated the study and wrote the manuscript; EB and KC carried out the molecular genetic studies; JL participated in performing molecular studies; WK coordinated the collection of tissue samples; AC-M participated in performing molecular studies and drafted the manuscript.

\section{Competing interests}

The authors declare that they have no competing interests.

Received: 20 December 2010 Accepted: 10 January 2011

Published: 10 January 2011

\section{References}

1. Joseph JD, Yeh ES, Swenson KI, Means AR, Winkler KE: The peptidyl-prolyl isomerase Pin1. Prog Cell Cycle Res 2003, 5:477-487.

2. Campbell HD, Webb GC, Fountain S, Young IG: The human PIN1 peptidylprolyl cis/trans isomerase gene maps to human chromosome 19p13 and the closely related PIN1L gene to 1p31. Genomics 1997, 44:157-162.

3. Stukenberg PT, Kirschner MW: Pin1 acts catalytically to promote a conformational change in Cdc 25. Mol Cell 2001, 7:1071-1083.

4. Wulf GM, Ryo A, Wulf GG, Lee SW, Niu T, Petkova V, Lu KP: Pin1 is overexpressed in breast cancer and cooperates with Ras signaling in increasing the transcriptional activity of c-Jun towards cyclin D1. EMBO J 2001, 20:3459-3472.

5. Wulf GM, Liou YC, Ryo A, Lee SW, Lu KP: Role of Pin1 in the regulation of p53 stability and p21 transactivation, and cell cycle checkpoints in response to DNA damage. J Biol Chem 2002, 277:47976-47979.

6. Ryo A, Nakamura M, Wulf G, Liou YC, Lu KP: Pin1 regulates turnover and subcellular localization of beta-catenin by inhibiting its interaction with APC. Nat Cell Biol 2001, 3:793-801.

7. Ryo A, Liou YC, Wulf G, Nakamura M, Lee SW, Lu KP: PIN1 is an E2F target gene essential for Neu/Ras-induced transformation of mammary epithelial cells. Mol Cell Biol 2002, 22:5281-5295.

8. Ayala G, Wang D, Wulf G, Frolov A, Li R, Sowadski J, Wheeler TM, Lu KP, Bao L: The prolyl isomerase Pin 1 is a novel prognostic marker in human prostate cancer. Cancer Res 2003, 63:6244-6251.

9. Bao L, Kimzey A, Sauter G, Sowadski JM, Lu KP, Wang DG: Prevalent overexpression of prolyl isomerase Pin1 in human cancers. Am J Pathol 2004, 164:1727-1737.

10. Wulf G, Ryo A, Liou YC, Lu KP: The prolyl isomerase Pin1 in breast development and cancer. Breast Cancer Res 2003, 5:76-82.

11. Rippmann JF, Hobbie S, Daiber C, Guillard B, Bauer M, Birk J, Nar H, GarinChesa P, Rettig WJ, Schnapp A: Phosphorylation-dependent proline isomerization catalyzed by Pin1 is essential for tumor cell survival and entry into mitosis. Cell Growth Differ 2000, 11:409-416.

12. Takahashi K, Uchida C, Shin RW, Shimazaki K, Uchida T: Prolyl isomerase, Pin1: new findings of post-translational modifications and physiological substrates in cancer, asthma and Alzheimer's disease. Cell Mol Life Sci 2008, 65:359-375.

13. Nakashima M, Meirmanov S, Naruke $Y$, Kondo H, Saenko V, Rogounovitch $T$, Shimizu-Yoshida Y, Takamura N, Namba H, Ito M, Abrosimov A, Lushnikov E, Roumiantsev P, Tsyb A, Yamashita S, Sekine I: Cyclin D1 overexpression in thyroid tumours from a radio-contaminated area and its correlation with Pin 1 and aberrant beta-catenin expression. J Pathol 2004, 202:446-455. 
14. DeLellis RA, Lloyd RV, Heitz PU, Eng C, (eds): World Health Organization classification of tumours: Pathology and genetics of tumours of endocrine organs. IARC Press, Lyon; 2004.

15. American Joint Committee on Cancer: Thyroid. AJCC Cancer Staging Manual. 6 edition. New York, NY: Springer; 2002, 77-87.

16. Lewiński A, Ferenc T, Sporny S, Jarząb B: Thyroid carcinoma: diagnostic and therapeutic approach; genetic background. Endocr Regul 2000, 34:99-113

17. Lewiński A, Wojciechowska K: Genetic background of carcinogenesis in the thyroid gland. Neuroendocrinol Lett 2007, 28:77-105.

18. Kimura ET, Nikiforova MN, Zhu Z, Knauf JA, Nikiforov YE, Fagin JA: High prevalence of BRAF mutations in thyroid cancer: genetic evidence for constitutive activation of the RET/PTC-RAS-BRAF signaling pathway in papillary thyroid carcinoma. Cancer Res 2003, 63:1454-1457.

19. Soares P, Trovisco V, Rocha AS, Lima J, Castro P, Preto A, Maximo V, Botelho T, Seruca R, Sobrinho-Simoes M: BRAF mutations and RET/PTC rearrangements are alternative events in the pathogenesis of PTC. Oncogene 2003, 22:4578-4580.

20. Frattini M, Ferrario C, Bressan $P$, Balestra D, De Cecco L, Mondellini $P$, Bongarzone I, Collini P, Gariboldi M, Pilotti S, Pierotti MA, Greco A: Alternative mutations of BRAF, RET, and NTRK1 are associated with similar but distinct gene expression patterns in papillary thyroid cancer. Oncogene 2004, 23:7436-7440.

21. Santoro M, Melillo RM, Fusco A: RET/PTC activation in papillary thyroid carcinoma: European Journal of Endocrinology Prize Lecture. Eur J Endocrinol 2006, 155:645-653.

22. Brzeziańska E, Karbownik M, Migdalska-Sẹk M, Pastuszak-Lewandoska D, Włoch J, Lewiński A: Molecular analysis of the RET and NTRK1 gene rearrangements in papillary thyroid carcinoma in the Polish population. Mutat Res 2006, 599:26-35.

23. Kuramochi J, Arai T, Ikeda S, Kumagai J, Uetake H, Sugihara K: High Pin1 expression is associated with tumor progression in colorectal cancer. J Surg Oncol 2006, 94:155-160.

24. Zhou CX, Gao Y: Aberrant expression of beta-catenin, Pin1 and cyclin D1 in salivary adenoid cystic adenoma: relation to tumor proliferation and metastasis. Oncol Rep 2006, 16:505-511.

25. Leung KW, Tsai CH, Hsiao M, Tseng CJ, Ger LP, Lee KH, Lu PJ: Pin1 overexpression is associated with poor differentiation and survival in oral squamous cell carcinoma. Oncol Rep 2009, 21:1097-1104.

26. Liou YC, Ryo A, Huang HK, Lu PJ, Bronson R, Fujimori F, Uchida T, Hunter T, Lu KP: Loss of Pin1 function in the mouse causes phenotypes resembling cyclin D1-null phenotypes. Proc Natl Acad Sci USA 2002, 99:1335-1340.

27. Brzeziańska E, Cyniak-Magierska A, Sporny S, Pastuszak-Lewandoska D, Lewiński A: Assessment of cyclin D1 gene expression as a prognostic factor in benign and malignant thyroid lesions. Neuroendocrinol Lett 2007, 28:341-350.

doi:10.1186/1756-6614-4-4

Cite this article as: Lewiński et al.: Increased expression of PIN1 gene in papillary thyroid carcinoma. Thyroid Research 2011 4:4.

\section{Submit your next manuscript to BioMed Central and take full advantage of:}

- Convenient online submission

- Thorough peer review

- No space constraints or color figure charges

- Immediate publication on acceptance

- Inclusion in PubMed, CAS, Scopus and Google Scholar

- Research which is freely available for redistribution

Submit your manuscript at www.biomedcentral.com/submit
Biomed Central 